ASEE's 123rd Annual • Conference \& Exposition • New Orleans, LA • June 26-29, 2016

\title{
Applied ABET Student Outcome Continuous Improvement Process
}

Prof. Byron G. Garry, South Dakota State University

BYRON GARRY is an Associate Professor and Undergraduate Program Coordinator in the Department of Construction \& Operations Management in the College of Engineering at South Dakota State University. He has been a member of ASEE since 1998. 


\title{
Applied ABET Student Outcome Continuous Improvement Process
}

\begin{abstract}
A sustainable continuous improvement process was desired for use in the ABET-ETAC accreditation process for an EET program. From the educational research field, it is known that programs must consider both an evidence-based continuous improvement process for internal purposes, as well as meeting the needs of external accountability. Programs need to assess and implement improvements in how well students are learning, which must be carried out in conjunction with improvements in their own program assessment process. There are also many considerations from a study of the field of quality, gathered from the program's foundation in the electronics manufacturing industry, which can be applied. Some of Deming's fourteen points on Total Quality Management, concepts and quality principles from the American Society for Quality, and principles from the ISO 9001-2015 quality management system standards can be applied to a student outcome continuous improvement process. For programs desiring ABET accreditation, there are specific requirements which must be documented, for how and when external and internal stakeholders are consulted. Another consideration growing in importance is the use of rubrics to help standardize evaluation of student work over time and audiences.

With all of these factors under consideration, our EET program has developed, and continues to use, a process that can be illustrated by a graphic that features three intersecting continuous improvement loops. This graphic helped the program to clarify the assessment, evaluation, and student learning improvement procedures. The EET program faculty have fully accepted and are implementing the process described. A table illustrates the assessment data reporting process used by the program, showing some of the assessment data gathered and improvement decisions made as this process was used over a five-year period in a capstone course.
\end{abstract}

\section{Keywords}

Assessment, Continuous Improvement, Accreditation

\section{Introduction}

The South Dakota State University Electronics Engineering Technology (EET) program received its initial ABET-ETAC Accreditation in 2006. In 2011, due to State of South Dakota funding cuts, the program was phased out, and accreditation was ended. In 2012, with the help of local industry support, the program was restarted, and is on track to have another "initial" accreditation visit in 2016. The EET program, as a program in the Department of Construction and Operations Management (COM), has defined, with the approval of alumni and its industrial advisory board, Student Outcomes labeled (a) - (1). These begin with the ABET ${ }^{1}$ Criterion 3. Student Outcomes (SO) (a) - (k), and then add (l) from the EET program specific requirements. The EET program assesses student progress on the outcomes all through the curriculum, generally gathering data on two to four SOs per course. We are also constantly re-evaluating the Criterion 2 Program Educational Objectives (PEO) and how graduates show that they are 
meeting them using the student outcomes assessment process. We believe that the program has a good balance of data collection practices in place. What the program did need, as the program was restarted in 2012, was improvement on how to be better and more efficient in setting up a sustainable continuous improvement process, for both program educational objectives and student outcomes. This paper explains that process.

\section{Higher Education Assessment}

Assessment can be defined as "the systematic collection, review, and use of information about educational programs undertaken for the purpose of improving students learning and development". . Although evidence of student learning has been emphasized by ABET for nearly 20 years, it is still only a growing importance that is being placed on standards that require institutions to provide evidence of student academic achievement ${ }^{3}$. The advancement of engineering education in many ways depends on assessment. High-quality assessments can provide educators with information they can use to move the field forward. Inadequate or poorly constructed assessments can cause educators to pursue ineffective paths, resulting in the loss of time, money, and energy ${ }^{4}$. The ultimate purpose of engineering education assessment should be to improve student learning, which begins with setting objectives and renews itself with each assessment activity ${ }^{4}$.

Ewell ${ }^{5}$, a leader in the higher education assessment field, states that there are "Four guiding principles for responding to calls for external accountability that also preserve and develop institutional capacity for evidence-based continuous improvement:

- Respond visibly to domains of legitimate external concern.

- Show action on the results of assessment.

- Emphasize assessment at the major transition points in a college career.

- Embed assessment in the regular curriculum."

A few of the major assertions of Pacific Crest's ${ }^{6}$ work on assessment includes:

- Assessment focuses on improvement, not judgment.

- Assessment is a process that can improve any level of performance.

- Assessment requires agreed-upon criteria.

- Assessment should be used only where there is a strong opportunity for improvement.

- Assessment is effective only when the assessee uses the feedback.

Another source of practical experience on assessment was published by the Advisory Committee for Academic Assessment at Kent State ${ }^{7}$. They say that assessment is needed for improvement, and improvement, with its internal focus, provides

- opportunities for the academic community to engage in self-reflection of its learning goals, to evaluate if students' activities, products, or performances coincide with the academic community's expectations;

- information to students about the knowledge, skills, and other attributes they can expect to possess after successfully completing coursework and academic programs.

- ways for academic units to understand the dimensions of student learning when seeking to improve student achievement and the educational process. 
- evidence of student achievement to accreditation groups, state legislators, and other stakeholders in education, as a function of accountability.

This last point falls under the umbrella of the phrase culture of evidence, which is currently popular among policy and assessment experts. It captures the belief that colleges can enhance student learning and success if they systematically collect and examine data ${ }^{8}$. Suskie ${ }^{9}$ states that $^{2}$ for good assessment to happen, the instructor at the start needs to "develop clearly articulated written statements of expected learning outcomes", that is, what the students know and will be able to do by the end of the course. Ewell ${ }^{5}$ calls this the "Improvement Paradigm", which can embrace many kinds of evidence-gathering, including standardized and faculty-designed examinations, capstone projects, demonstrations, portfolios, and specially designed assignments embedded in regular courses. All of these sources of evidence rely on evaluation using rubrics specially crafted scoring guides developed by faculty". "Simply put, assessment is a process used for improving quality." "Measurement of student achievement of outcomes is the base for improvement, but an efficient, sustainable continuous improvement process must be in place before improvements can be made.

\section{Quality Concepts and Definitions}

The American Society for Quality (ASQ) sets standards, and provides education for how quality can be implemented and maintained in a variety of different situations. ASQ defines quality ${ }^{10}$ as:

A subjective term for which each person or sector has its own definition. In technical usage, quality can have two meanings: 1 . the characteristics of a product or service that bear on its ability to satisfy stated or implied needs; 2 . a product or service free of deficiencies. According to Joseph Juran, quality means "fitness for use;" and according to Philip Crosby, it means "conformance to requirements."

ASQ defines continuous improvement ${ }^{11}$ as an ongoing effort to improve products, services or processes. These efforts can seek "incremental" improvement over time or "breakthrough" improvement all at once. The ISO $9001-2015^{12}$ standard is used by manufacturers to assess whether they are following a good continuous improvement process. When used within a quality management system, such an approach emphasizes the importance of understanding and meeting the customer's, as well as all relevant interested parties, requirements, the need to consider processes in terms of added value, obtaining results of process performance and effectiveness, and continual improvement of processes based on objective measurement. Figure 1 shows a graphic from the ISO 9001-2015 Standards document illustrating one example of a continuous improvement process. 


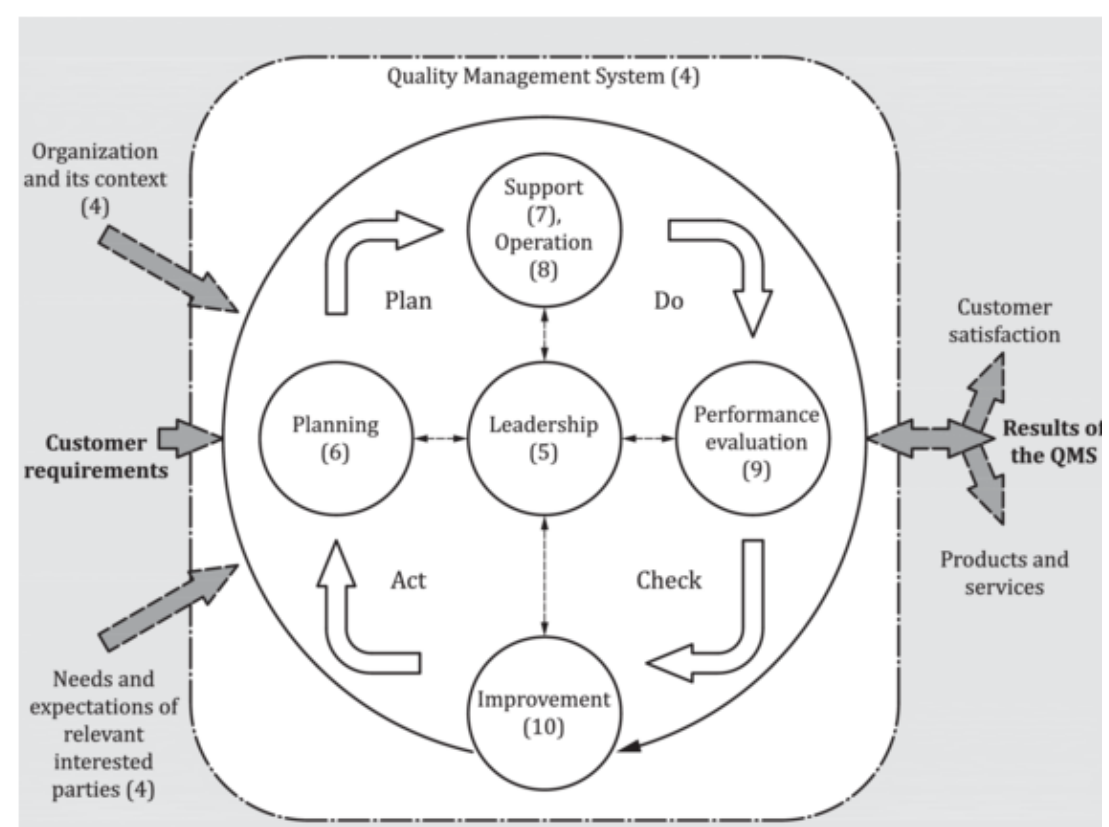

Figure 1. ISO 9001-2015 Continuous Improvement Process ${ }^{12}$

This graphic includes the Shewart Cycle, also known as "Plan-Do-Check-Act" (PDCA), which can be applied to many processes. PDCA ${ }^{11}$ can be described as follows.

Plan: establish the objectives and processes necessary to deliver results in accordance with customer requirements and the organization's policies.

Do: implement the processes.

Check: monitor and measure processes and product against policies, objectives and requirements for the product and report the results.

Act: take actions to continually improve process performance.

The terms "quality assurance" and "quality control" are often used interchangeably to refer to ways of ensuring the quality of a service or product. The terms, however, have different meanings. For use by the EET program ${ }^{13}$, we have developed and use these definitions: Quality Assurance (QA) is an end-of-cycle test:

- In manufacturing, we evaluate products at the end of a process to make sure they are good, and ready for the customer.

- In engineering education, there is the tendency to use Senior Exit Exams, or FE Test results, as the only means of program assessment.

Whereas Quality Control (QC) is an in-process or embedded technique:

- In manufacturing, processes are monitored, to identify problems that could lead to nonconforming products

- Corrective action can be taken quickly, after each semester.

- Can also be used to test new materials, equipment, and methods. If a test did not work well, then fixing it can happen the next time the test is given.

The EET continuous improvement process uses mostly embedded assessments, that is, the assignments, quizzes, tests, labs, reports and projects that are a part of the grading of the course are used as the assessment tool. A specific rubric is developed to apply to each instrument to 
assure that we look at the specific SO (a) - (1) we are assessing. This is detailed later in the paper.

Another major source of ideas in quality comes from Deming. Two of Deming's 14 Points on Total Quality Management ${ }^{14}$, are especially relevant to continuous improvement in an educational environment: Cease dependence on mass inspection, and Improve constantly and forever every process for planning, production and service. In a manufacturing process "mass inspection" is used to find and remove defects in products before they are sent to the customers. With mass inspection we hope to assure that customers are satisfied with a product and do not require expensive warrantee repairs or product recalls. In the educational process, we use exams in a similar fashion to weed out "defective" students. Students are required to learn the course material, and if they do not, we must penalize their performance. ${ }^{14}$ Deming and other quality experts probably would not argue against the need for mass inspection. They would argue, however, that improvement of a process, in this case, the university course in which the student is learning the material, is a much better way to create a better product. Fewer defects would be found in the output of an improved process. Also, mass inspection often does not provide a good mechanism for finding ways to improve the process.

ASQ defines sampling ${ }^{16}$ as is the selection of a set of elements from a population or product lot. Sampling is frequently used because data on every member of a population are often impossible, impractical, or too costly to collect. Sampling requires conclusions or making inferences about the population from which the sample is drawn. In our EET program's continuous improvement process we sample student work to use as measurements of SOs, that is, we do not assess every assignment in every course (mass inspection). Not attempting to assess all student work allows us to limit the number data points to gather and use. Note, the EET program calls for assessing the work of all students in the chosen assignment that semester. Also we usually do not attempt to do statistical analysis of the assessment data, beyond what percentage of students met the assessment goal.

Another quality idea that has not been applied to the world of assessment, and should be referenced more often, is cost. Quality $\operatorname{cost}^{17}$ are the total of the cost incurred by:

- Investing in the prevention of nonconformance to requirements.

- Appraising a product or service for conformance to requirements.

- Failing to meet requirements.

The costs of students failing to meet the student learning goals of an academic program are not currently measured, and in fact are probably not measureable. Since the costs are not known, the consequences are not known, either. Most faculty involved in the process of assessment and evaluation, seeing the costs of their time and effort only, approach the quality process as a necessary evil to satisfy the requirements of their institution. Using assessment and evaluation of data to improve the quality of student learning is not made clear in most institutions, and so a better continuous improvement process, where the results of increase in quality may be seen, is needed. 
One more quality tool that can be applied to our assessment process is the stop light analogy ${ }^{18}$. This is a visual technique that draws attention to processes that are most in need of improvement. Charts are made, and posted where all can see, with a color code:

- Green = The process performance is stable and acceptable.

- Yellow $=$ Warning, the process may be having performance stability problems.

- $\quad \operatorname{Red}=$ The process has become unstable and the performance is unacceptable.

In our EET program's continuous improvement process documentation, we chose to use the colors white, yellow, and red, as is detailed below.

\section{Accreditation and Assessment using Continuous Improvement Terminology}

Accreditation is the principle mechanism currently in use in the US for assuring academic quality. It has been in place for 125 years and for some 60 years in its current form. ${ }^{3}$ ABET 2015-16 Criterion 4 Continuous Improvement ${ }^{1}$ states:

The program must regularly use appropriate, documented processes for assessing and evaluating the extent to which the student outcomes are being attained. The results of these evaluations must be systematically utilized as input for the continuous improvement of the program. Other available information may also be used to assist in the continuous improvement of the program.

Continuous improvement can be defined as "a systematic effort to seek out and apply new ways of doing work, which is actively and repeatedly making process improvements". ${ }^{19}$ Processes are also defined as a "designed sequences of tasks aimed at creating value-adding transformations of inputs - material and information - to achieve intended outputs". ${ }^{19}$ A continuous improvement initiative provides a planned and organized system for the continual discovery and implementation of such process changes. Pacific $\mathrm{Crest}^{20}$ makes a point to note that the practice of continuous improvement applies not only to measuring student outcome performance, but also to the assessment systems that are used to assess programs. Assessment systems that are efficient and current are less time consuming to employ and are more likely to yield reliable data. Therefore, it is crucial to review assessment systems with the goal of continuously improving the process.

Gloria Rogers ${ }^{21}$ states that data collection activities must be examined in light of good program assessment practice, efficiency, and reasonableness. She says several questions need to be asked, such as, "Is there a clear vision of why specific data are being collected?" She answers, "Without clearly defined outcomes, there can never be enough data because there is no focus." The National Academy of Engineering in 2009 issued a report called "Developing Metrics for Assessing Engineering Instruction: What Gets Measured is What Gets Improved." ${ }^{22}$ In that report they reinforced the idea that a sustainable evaluation system must not require implementation that is burdensome to faculty or administrators.

Rubrics are also an important part of an educational quality control process. Rubrics can be defined as descriptive scoring schemes that are developed by teachers or other evaluators to guide the analysis of the products or processes of students' efforts. ${ }^{23}$ The use of a rubric is more likely to provide meaningful and stable appraisals than are traditional scoring methods. Assessing student's knowledge and skills on the basis of a scale offers several advantages. First, 
it presents a continuum of performance levels, defined in terms of selected criteria, towards to full attainment or development of the targeted skills. Second, it provides qualitative information regarding the observed performance in relation to a desired one. Third, its application, at regular intervals, tracks the student's progress of his or her skill mastery. ${ }^{24}$ In our EET program's continuous improvement process, rubrics are developed by faculty, reviewed and approved by a committee of faculty, and used to evaluate student work each time a course is taught.

Spurlin, Rajala and Lavelle ${ }^{25}$ illustrated the overlapping and inter-twined aspect of both assessing how well students are learning, and also the important duty of assessing the assessment system. The graphic they produced, shown in Figure 2, helps to clarify who is responsible for what actions, and then shows who should use the results of those actions in the next step of a process. The figure, though illustrative of what has to happen in a good continuous improvement process, does not provide an operational, process to emulate. In our EET continuous improvement process, we chose to use the idea of interlinking cycles, but created more detailed and separated loops.

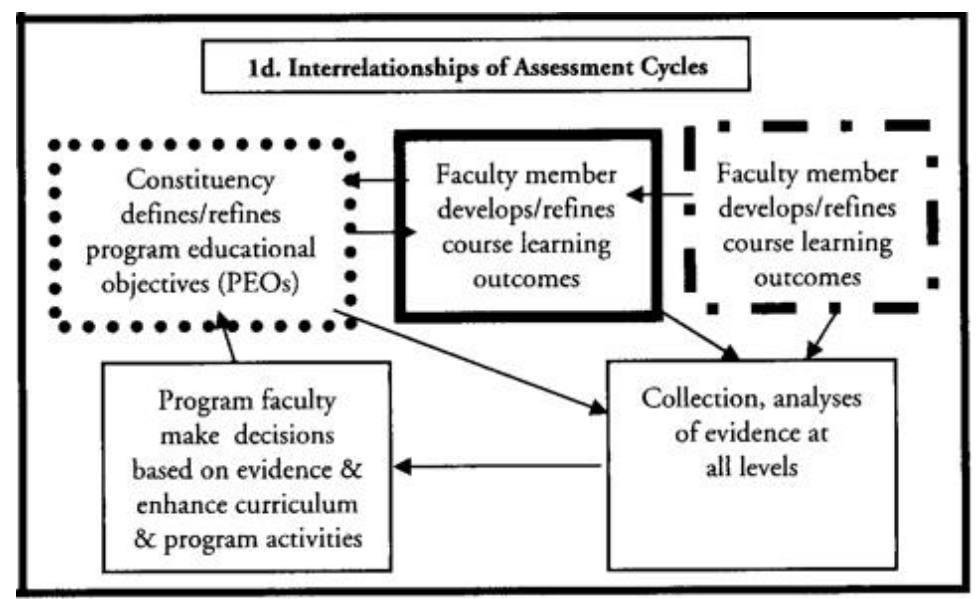

Figure 2. Interrelationships of Assessment Cycles $^{25}$

\section{Using the EET program Continuous Improvement Process}

Considering the state of assessment requirements in higher education, ABET accreditation standards, and the tools of quality and continuous improvement in mind, our EET program uses a process that can be illustrated by a graphic that features three intersecting continuous improvement loops. ${ }^{26}$ This graphic helped to clarify in our minds the assessment, evaluation, and student learning improvement processes we had been doing for several years. Each loop is a complete PDCA process, carried on at different repetition rates, with different goals and quality targets in mind, as stated in the graphic, as shown in Figure 3. For the purposes of brevity in this paper, this figure is reproduced too small to see the details. Following in the text, each loop is broken out and explained. 


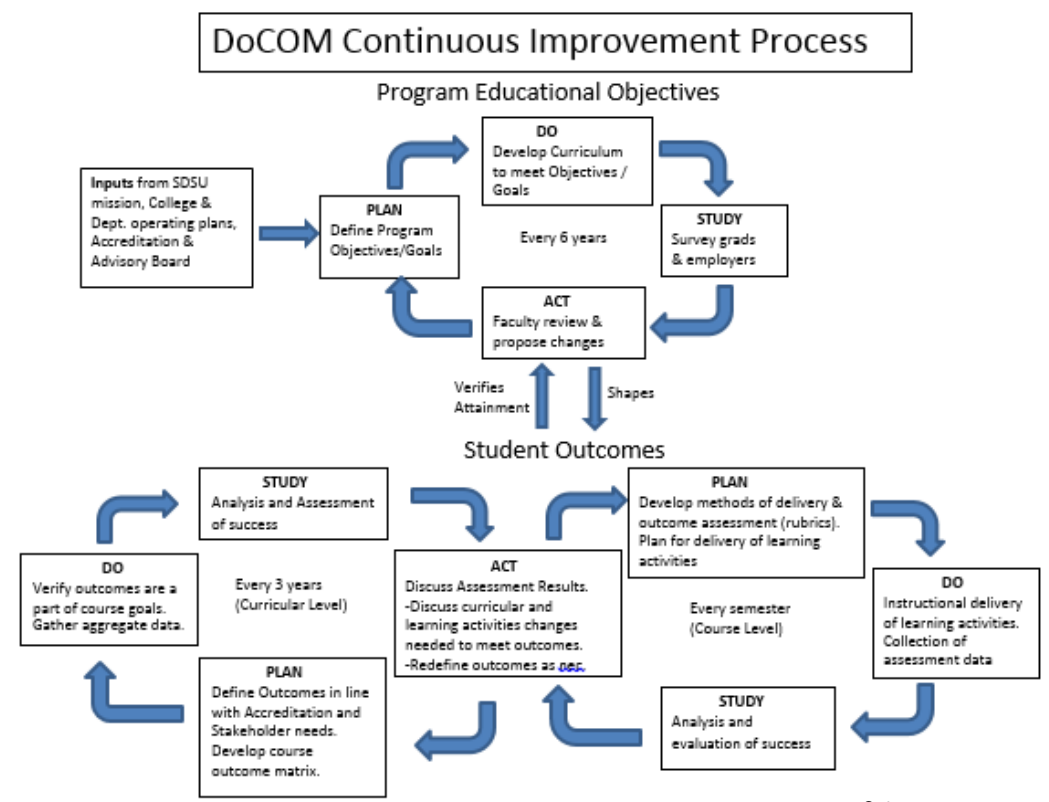

Figure 3. Complete Three-Loop Continuous Improvement Process ${ }^{26}$

There is one PEO loop, and two SO loops, and wording that details what is happening in the intersections of the loops.

The top loop, shown in Figure 4, applies to the ABET Criterion 2 Program Educational Objectives (PEOs) only. The figure illustrates that we are using input from our constituents, developing a plan that states the objectives, setting a curriculum that we think will educate the students to meet the objectives, surveying graduates and employers to check if the objectives were met, and then using the survey results to propose changes for the next iteration of the loop. This loop is repeated, ideally, every 6 years, as the overall, big picture, program educational objectives should be fairly constant over time. In practice, especially as the EET program was restarted in 2012, working toward a 2016 accreditation visit, the loop was repeated every two years.

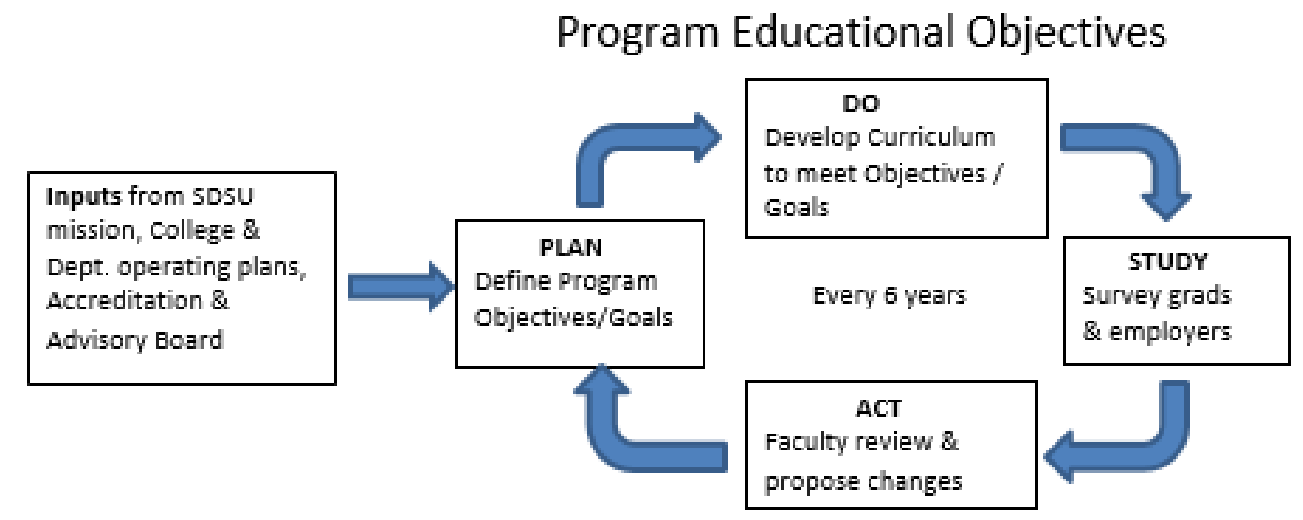

Figure 4: Program Educational Objectives Loop ${ }^{26}$ 
The lower-left loop, as shown in Figure 5, deals with the definition of Student Outcomes (SO), and when there could be significant changes to the EET curriculum, which should occur every three years. Again, as we restarted the EET program, we traversed this loop on a yearly basis. In this loop we maintain our course outcome matrix, that is, deciding in which course we will assess which SO (a) - (1). The data gathered each semester is summarized over time. The purpose of this loop is to decide if bigger, curriculum-level changes need to be made, for example if there is a need to switch program content from one course to another, or to add courses to the curriculum, if we determine that is needed for students to learn what is needed by an EET graduate.

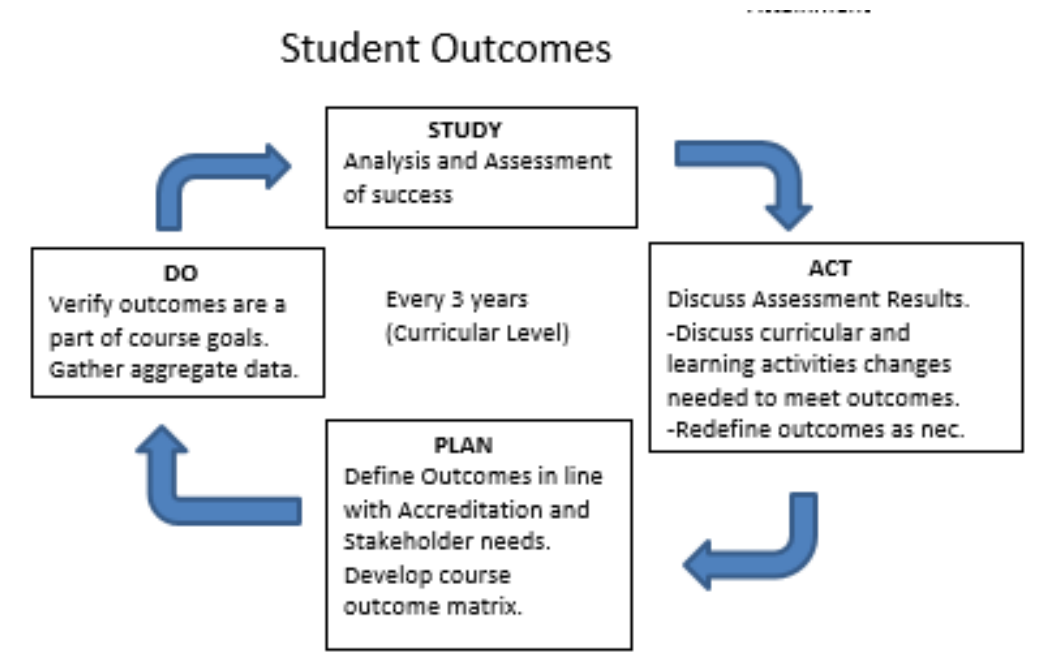

Figure 5: Considering the Student Outcome Statements Loop ${ }^{26}$

The lower-right loop, shown in Figure 6, deals with the assessment and evaluation of student outcomes data that we gather each semester. Again, using a PDCA process we let each faculty member decide on the tools they will use to assess the outcomes chosen for that course, decide on a rubric to use, gather student data throughout the semester and apply the rubric, and evaluate results to see if students met the goals that have been set.

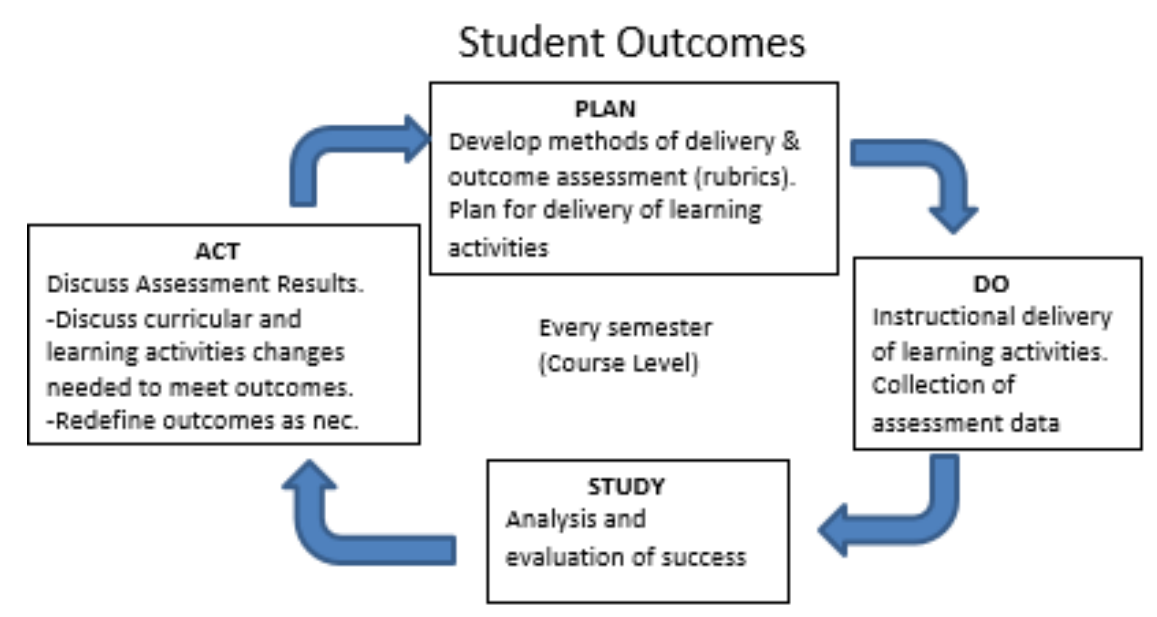

Figure 6. Review Whether Students Meet Selected SO Goals every Semester ${ }^{26}$ 
If it is determined that students, as a group, do not meet a course's SO goal, then faculty make small changes in course sequence, the tests and/or projects that are assessed, or when assessments will be made. This loop overlaps with Figure 5 loop, in that if the faculty as a whole decide that small changes will not be enough to improve students' learning then bigger curriculum changes are proposed and approved. For this paper, the results of some of the assessment from the EET Capstone course over a five-year period were chosen to illustrate the overall continuous improvement process and its documentation. In the capstone project, we choose to assess, among others, SOs (e), (f), (k), and (1). In this loop rubrics are used, and Table 1 shows examples of the rubrics used for these SOs.

\begin{tabular}{|c|c|c|c|c|c|}
\hline \multicolumn{6}{|c|}{ Capstone Project Rubrics } \\
\hline \multirow{2}{*}{$\begin{array}{l}\text { ABET-ETAC } \\
\text { Student } \\
\text { Outcome }\end{array}$} & Superior & \begin{tabular}{|l} 
Excellent \\
\end{tabular} & Good & Fair & Poor \\
\hline & $100 \%$ & $90 \%$ & $80 \%$ & $70-60 \%$ & $\begin{array}{c}50 \% \text { and } \\
\text { below }\end{array}$ \\
\hline \multirow{3}{*}{$\begin{array}{l}\text { e) an ability to } \\
\text { function } \\
\text { effectively as a } \\
\text { member or } \\
\text { leader on a } \\
\text { technical team }\end{array}$} & $\begin{array}{l}\text { Completes all assigned } \\
\text { tasks by deadline } \\
\text { without prompting }\end{array}$ & $\begin{array}{l}\text { Completes all } \\
\text { assigned tasks by } \\
\text { deadline }\end{array}$ & $\begin{array}{l}\text { most } \\
\text { tasks }\end{array}$ & some tasks & few tasks \\
\hline & $\begin{array}{l}\text { Work accomplished is } \\
\text { thorough, } \\
\text { comprehensive, and } \\
\text { advances the project }\end{array}$ & $\begin{array}{l}\text { Work accomplished } \\
\text { is thorough and } \\
\text { advances the project }\end{array}$ & mostly through & $\begin{array}{l}\text { does not } \\
\text { advance }\end{array}$ & $\begin{array}{l}\text { little work } \\
\text { done }\end{array}$ \\
\hline & $\begin{array}{l}\text { Proactively helps other } \\
\text { team members } \\
\text { complete their assigned } \\
\text { tasks to a similar level } \\
\text { of excellence }\end{array}$ & $\begin{array}{l}\text { Works with other } \\
\text { team members as } \\
\text { required. }\end{array}$ & $\begin{array}{l}\text { only with } \\
\text { prompting }\end{array}$ & $\begin{array}{l}\text { only on } \\
\text { some tasks }\end{array}$ & $\begin{array}{l}\text { works } \\
\text { poorly with } \\
\text { team } \\
\text { members }\end{array}$ \\
\hline \multirow{3}{*}{$\begin{array}{l}\text { f) ability to } \\
\text { identify, } \\
\text { analyze and } \\
\text { solve problems }\end{array}$} & $\begin{array}{l}\text { Design process } \\
\text { completely detailed }\end{array}$ & Mostly detailed & $\begin{array}{l}\text { Basically } \\
\text { detailed }\end{array}$ & $\begin{array}{l}\text { Sketchily } \\
\text { detailed }\end{array}$ & $\begin{array}{l}\text { Not } \\
\text { detailed }\end{array}$ \\
\hline & $\begin{array}{l}\text { All appropriate } \\
\text { supporting documents } \\
\text { in written report }\end{array}$ & Mostly & Somewhat & Few & No \\
\hline & $\begin{array}{l}\text { Clear understanding of } \\
\text { design process } \\
\text { demonstrated }\end{array}$ & Mostly clear & $\begin{array}{l}\text { Somewhat } \\
\text { clear }\end{array}$ & Fair & Poor \\
\hline \multirow[t]{2}{*}{$\begin{array}{l}\text { k) commitment } \\
\text { to quality, } \\
\text { timeliness and } \\
\text { continuous } \\
\text { improvement }\end{array}$} & $\begin{array}{l}\text { Reasons with all } \\
\text { good/correct results } \\
\text { and/or interprets data } \\
\text { very well. }\end{array}$ & $\begin{array}{l}\text { Mostly good/correct } \\
\text { results and/or } \\
\text { interprets data well. }\end{array}$ & $\begin{array}{l}\text { Some good } \\
\text { results and } \\
\text { some data } \\
\text { interpreted well }\end{array}$ & $\begin{array}{l}\text { Minimal } \\
\text { results, } \\
\text { interprets a } \\
\text { small amount } \\
\text { of data well }\end{array}$ & $\begin{array}{l}\text { Poor results } \\
\text { and/or } \\
\text { interprets } \\
\text { data poorly }\end{array}$ \\
\hline & $\begin{array}{l}\text { Develops exemplary } \\
\text { conclusions based on } \\
\text { results. }\end{array}$ & $\begin{array}{l}\text { Good conclusions } \\
\text { based on results. }\end{array}$ & \begin{tabular}{|l} 
Some good \\
conclusions \\
based on some
\end{tabular} & $\begin{array}{l}\text { Minimal } \\
\text { conclusions }\end{array}$ & $\begin{array}{l}\text { Poor } \\
\text { conclusions }\end{array}$ \\
\hline $\begin{array}{l}\text { 1) apply project } \\
\text { management } \\
\text { techniques }\end{array}$ & $\begin{array}{l}\text { Project is planned } \\
\text { thoroughly and } \\
\text { completely, and } \\
\text { executed very closely } \\
\text { to plan }\end{array}$ & $\begin{array}{l}\text { Project is planned } \\
\text { thoroughly, and } \\
\text { executed mostly to } \\
\text { plan }\end{array}$ & $\begin{array}{l}\text { Planned } \\
\text { thoroughly, } \\
\text { and executed } \\
\text { far from plan }\end{array}$ & $\begin{array}{l}\text { Planned } \\
\text { loosely, and } \\
\text { executed far } \\
\text { from plan }\end{array}$ & $\begin{array}{l}\text { Little plan, } \\
\text { and } \\
\text { execution } \\
\text { haphazard }\end{array}$ \\
\hline
\end{tabular}

Table 1. Some of the Rubrics used in the EET SO Loop ${ }^{26}$ 
Table 2 shows the some of the documented results over those five years of assessment in the EET Capstone course, and illustrates our use of the stop light analogy to help us focus on when the students are not meeting the learning goals that we set. As the figure shows, we set our quality goal as: "Unless otherwise noted, the given percentage meets the goal set by the EET program. For most assessment points, the goal is for $80 \%$ of the students to reach $80 \%$ or higher, as evaluated using a rubric, on an assignment, quiz, test, report, or project." Note: The example assessment data is not being presented in graphical form in this paper, as the main focus of the paper is the assessment process and documentation that was developed.

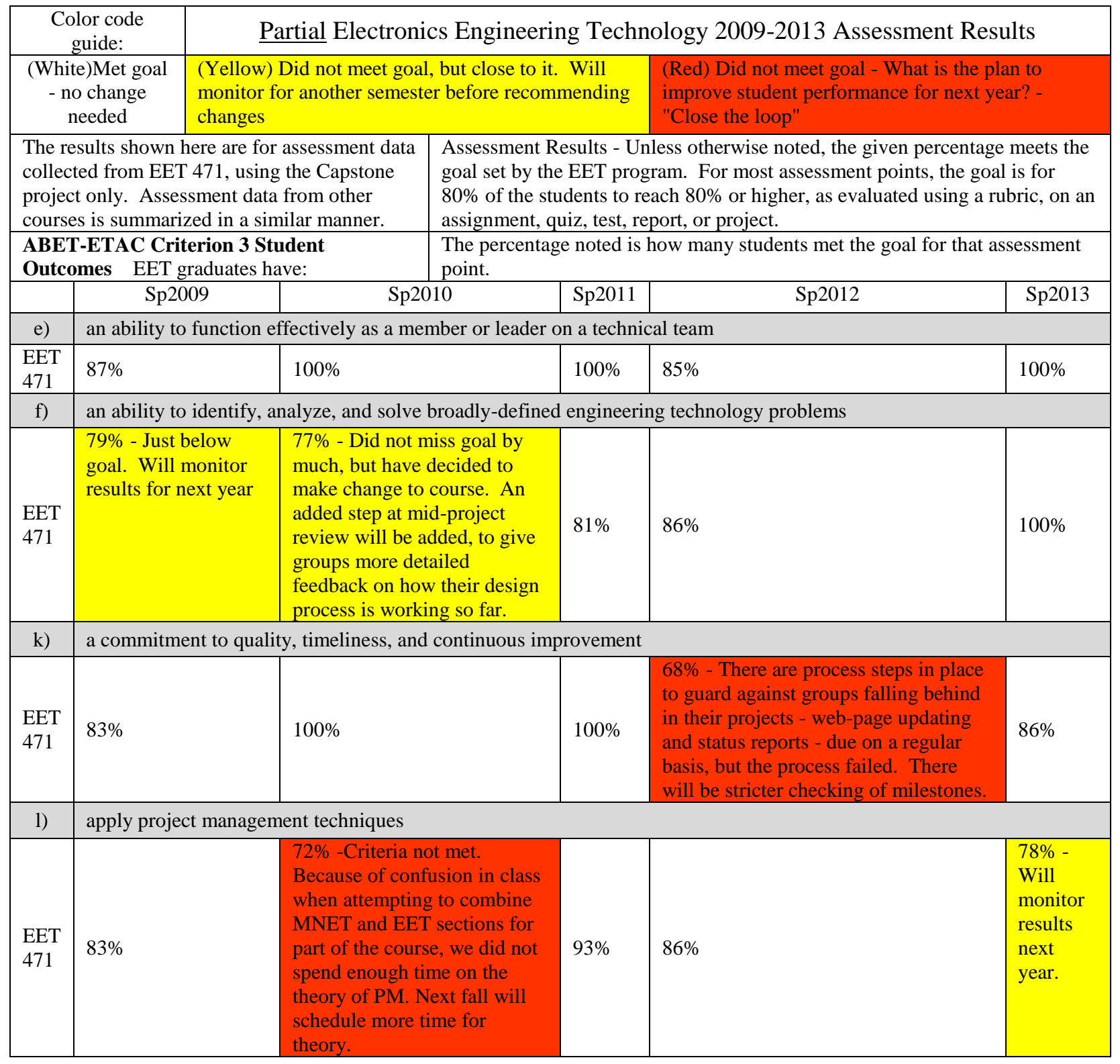

Table 2. Example Selected Capstone Project course assessment results and continuous improvement decisions made over five years, highlighted using the stop light technique ${ }^{26}$ 
Each time a learning goal is not met, the faculty member chooses what they will do to change the course the next time it is taught, either in a minor or major way. If the goal was close to being met, then the result is marked with yellow and a change may not be made at all. This is following the quality principle that over-reacting to data that is only slightly missing the goal is not a good practice. If the goal is missed by a large margin, the result is marked red, and a major course change may be made. As is seen in the data illustrated in Table 2, each time the assessment shows that a goal is not being met, marked by red, the next year the change in the course resulted in the goal being met. This does not always happen. Groups of students vary from semester to semester, and an improvement in how a course is taught may not have the desired results the next time the class is taught. The most important consideration is that a continuous plan is in place, and the fact that student learning is being monitored.

\section{Conclusion}

A sustainable continuous improvement, one that is accepted and used regularly by all faculty in the program, is the goal of any ABET accredited program. We have created a graphic that helps us to keep separate, and be more efficient with, the process of assessment data collection, evaluation of the data, and changes made to improve student learning using the data. As the process has been implemented, the EET program faculty have accepted the time and effort that the good assessment takes, and have bought into the process. The same assessment process is being used by the Construction Management and Operations Management programs, also in the SDSU COM Department. Those faculty have also accepted and have implemented the comprehensive assessment process required, as they also prepare for an ABET Accreditation visit. It is a process the COM Department feels comfortable with for now, and plan to use in the years to come. We know, however, that the process itself is subject to review and evaluation for how well it is working, and so is subject to change over time.

\section{References}

1 ABET 2015-16 ETAC Criteria, Retrieved from http://www.abet.org/wp-content/uploads/2015/05/T001-15-16ETAC-Criteria-05-04-15.pdf

2 Palomba, C.A. and T.W. Banta, Assessment Essentials: Planning, Implementing and Improving Assessment in Higher Education, Stylus, Sterling, VA, 1999

3 Ewell, P. T., "The Quality Agenda: An overview of current efforts to examine quality in higher education. A discussion paper prepared for the American Council on Education", 2012, Retrieved from http://www. acenet.edu/news-room/Documents/The-Quality-Agenda-An-Overview-of-Current-Efforts-to-Examine-Qualityin-Higher-Education--Ewell.pdf.

4 Olds, B.M., B.M. Moskal and R.L. Miller, "Assessment in Engineering Education: Evolution, Approaches and Future Collaborations," Journal of Engineering Education, 2005, 94(1):13-25.

5 Ewell, P. “Assessment, Accountability and Improvement: Revisiting the Tension," National Institute for Learning Outcomes Assessment, 2009, Retrieved from http://www.learningoutcomeassessment.org/ occasionalpaperone.htm

6 Baehr, M. and S. W. Beyerlein, "Overview of Assessment, “ In S. Beyerlein, C. Holmes \& D. Apple (Eds.), Program Assessment Handbook, Pacific Crest. 2010, (pp. 3-6). Retrieved from http://www.pcrest2.com/institute_resources/PAI/PAI2010_020910.pdf

7 Advisory Committee for Academic Assessment, Kent State, Six Steps to Continuous Improvement of Student Learning, no date. Retrieved from http://explore.kent.edu/aa/guide/fulltext.html 
8 Morest, V.S., “Accountability, Accreditation, and Continuous Improvement: Building a Culture of Evidence," New Directions for Institutional Research, no. 143, Fall 2009

9 Suskie, L., "Understanding the Nature and Purpose of Assessment," In Designing Better Engineering Education through Assessment. Spurlin, J.E, Rajala, S.A., and J.P. Lavelle, eds., 2008, Stylus Publishing, Sterling, VA

10 ASQ Quality, Glossary - Q, Retrieved from http://asq.org/glossary/q.html

11 ASQ Continuous Improvement, Retrieved from http://asq.org/learn-about-quality/continuousimprovement/overview/overview.html

12 Quality management systems-Requirements, ISO 9001-2015 Standard, Retrieved from https://www.iso.org/obp/ui/\#iso:std:iso:9001:ed-5:v1:en

13 Embedded assessment: quality control vs. quality assurance. 2009. Presentation at Teaching Learning Center Faculty Development Series, South Dakota State University.

14 Deming's 14 Points on Total Quality Management, Retrieved from http://asq.org/learn-about-quality/totalquality-management/overview/deming-points.html

15 Jensen, P.A., and J.K. Robinson, "Deming's Quality Principles Applied to a Large Lecture Course," Journal of Engineering Education, 1995, 84(1):1-6

16 ASQ Sampling, Retrieved from http://asq.org/learn-about-quality/sampling/overview/overview.html

17 ASQ Total Quality Costs, Retrieved from http://asq.org/learn-about-quality/cost-ofquality/overview/overview.html

18 Flaig, J.J., "The Lights are on But Nobody is Home," Retrieved from http://d577289.u36.websitesource.net/articles/Flaig_StopLight.htm

19 Anand, G., P.T. Ward, M.V. Tatikonda, and D.A. Schilling, "Dynamic capabilities through continuous improvement infrastructure," Journal of Operations Management, 2009, 27:444-461

20 Parmley, K. \& D.K. Apple, “Assessing Program Assessment Systems,” In S. Beyerlein, C. Holmes \& D. Apple (Eds.), Program Assessment Handbook, Pacific Crest. 2010, pg 71-74, Retrieved from http://www.pcrest2.com/institute_resources/PAI/PAI2010_020910.pdf

21 Rogers, G. "When is Enough Enough?” ABET Community Matters Newsletter, 2007, Retrieved from http://drjj.uitm.edu.my/DRJJ/OBE FSG Dec07/OBEJan2010/DrJJ-Assessment Tips-ABET-GloriaRogers.pdf

22 National Academy of Engineering, Developing Metrics for Assessing Engineering Instruction: What Gets Measured is What Gets Improved, Report from the Steering Committee for Evaluating Instructional Scholarship in Engineering, 2009, Retrieved from http://www.nap.edu/catalog/12636.html

23 Brookhart, S. M. "The Art and Science of Classroom Assessment: The Missing Part of Pedagogy," ASHEERIC Higher Education Report (Vol. 27, No.1), 1999, George Washington University, Graduate School of Education and Human Development, Washington, DC. Retrieved from http://files.eric.ed.gov/fulltext/ED432937.pdf

24 Simon, M. \& Forgette-Giroux, R. (2001). A rubric for scoring postsecondary academic skills, Practical Assessment, Research \& Evaluation, 7(18). Retrieved from http://pareonline.net/getvn.asp?v=7\&n=18

25 Spurlin, J.E, S.A. Rajala, and J.P. Lavelle, "Assessing Student Learning: Ensuring Undergraduate Students are Learning What We Want Them to Learn," In Designing Better Engineering Education Through Assessment, Ed. J.E. Spurlin, S.A. Rajala, and J.P. Lavelle, 2008, Stylus Publishing, Sterling, VA, pg. 23-38.

26 SDSU COM Department Continuous Improvement Process, 2012, Internal Document 